\title{
PD184352 Releases the Regular Hypoxic Reversible DNA Replication Arrest in T24 Cells
}

\author{
Leenus Martin \\ Interfakultäres Institut für Biochemie der Universität Tübingen, Hoppe-Seyler-straße 4, D-72076 Tübingen, Germany
}

Received 27 March 2007, Accepted 26 June 2007

\begin{abstract}
The oxygen dependent regulation of DNA replication is an essential property of proliferating mammalian cells. In human T24 bladder cancer cells, several hours of hypoxia leads to reversible DNA replication arrest and re-entry of oxygen induces a burst of replication initiation. This short communication provides strong evidence that PD184352 initiates DNA replication in living hypoxic cells without elevating the oxygen level. PD184352 releases the regular hypoxic replicon arrest, however, at a low intensity compared to the effect of reoxygenation. Moreover, PD184352 shows no effect on normoxically incubated as well as reoxygenated T24 cells.
\end{abstract}

Keywords: Hypoxia, PD184352, Reoxygenation, Replication, T24 cells

\section{Introduction}

Hypoxia-induced DNA replication arrest is an essential property of proliferating mammalian cells, serving basal function, such as protection against metabolic catastrophes during embryonic development or wound healing and in tumour growth (Probst et al., 1999). So far, this oxygen dependent regulation of DNA replication has been shown in all types of cells examined during the past 20 years, ranging from cells replicating a virus (SV40) over a diversity of tumour cell lines to normal human primary explanted from umbilical cord vein (HUVEC) and nasal epithelium (HNEpC) (Probst, G, Probst, H., Gekeler, V., to be published). In human T24 bladder cancer cells, the especially elevated starvation protocol accumulates the cells in G1 phase and cells enter to S-Phase after medium renewal (van Betteraey-Nikoleit et al., 2003). The several hours of hypoxia directly after medium

*To whom correspondence should be addressed.

Tel: 49-7071-29-73329; Fax: 49-7071-29-3339

E-mail: lee casmir@yahoo.com renewal of starved T24 cells arrests the replicon initiation reversibly (no replication is reported) and it enters into a synchronous wave of replicon initiations by elevating the oxygen level (van Betteraey-Nikoleit et al., 2003; Stabenow et al., 2005). On the other hand, PD184352 is a well known ERK MAP kinase pathway inhibitor and inhibition of ERKMAP pathway leads to cell cycle arrest in different cell lines (Sebolt-Leopold et al., 1999; Milella et al., 2001; Squires et al., 2002). However, this short communication provides a new approach of PD184352 in oxygen dependent regulation of mammalian DNA replication. PD184352 releases the hypoxiainduced replicon arrest and it stimulates the replicon initiation in living hypoxic T24 cells without re-administration of oxygen. Thereby, this report provides evidence that involvement of other cell cycle kinases in oxygen dependent regulation of DNA replication. However, the releasing mechanism of PD184352 in hypoxic reversible replicon arrest is still largely unknown.

\section{Material and Methods}

Cell culture, normoxia, transient hypoxia, reoxygenation and radioactive labeling. T24 cells (ATCC No. HBT-4) were grown in plastic flasks in DMEM supplemented with $10 \%$ fetal calf serum and penicillin/streptomycin $\left(100 \mathrm{U} / 100 \mu \mathrm{g} \cdot \mathrm{mL}^{-1}\right)$. The cells were subcultured when they reached confluence. Under these conditions, the cells exhibited a partially tetraploid caryotype. For synchronization, the desired number of glass petri dishes was seeded, $44 \mathrm{~h}$ before the start of an experiment, from an almost confluent large culture with 150,000 cells $\cdot \mathrm{mL}^{-1}(35 \mathrm{~mm}, 1.5 \mathrm{~mL} ; 145 \mathrm{~mm}, 25 \mathrm{~mL})$. After $44 \mathrm{~h}$, most of the cells became arrested in G1-phase due to starvation (van Betteraey-Nikoleit et al., 2003). For prelabeling the DNA, the seeding medium was supplemented with $5 \mathrm{nCi} \cdot \mathrm{mL}^{-1}{ }^{14} \mathrm{C}$-thymidine. Experiments were started by stimulation of the cells by a complete exchange of the culture medium with prewarmed fresh medium supplemented with $10 \%(\mathrm{v} / \mathrm{v})$ fetal calf serum. For inhibitor treatment, PD184352 $(10 \mu \mathrm{M})$ was added to the cells directly after medium renewal of starved T24 cells. Subsequent gassing of the cell cultures was performed with a continuous flow of humidified 
artificial air containing $5 \%(\mathrm{v} / \mathrm{v}) \mathrm{CO}_{2}$ for normoxic incubations, and with $0.0075 \% \mathrm{O}_{2}, 5 \% \mathrm{CO}_{2}$, and $\mathrm{Ar}$ ad $100 \%$ for hypoxia. This hypoxic gassing protocol diminished the $\mathrm{pO}_{2}$ in the cultures within $1.5-2 \mathrm{~h}$ to about $0.1 \%$ and within $6-7 \mathrm{~h}$ to about $0.02 \%$. The equipment and the procedures used have been described in Dreier et al. (1993). For reoxygenation, 0.25 volumes of medium equilibrated with $95 \% \mathrm{O}_{2} / 5 \% \mathrm{CO}_{2}(\mathrm{v} / \mathrm{v})$ were added to the hypoxic cultures, and gassing was continued with artificial air. [Methyl$\left.{ }^{3} \mathrm{H}\right]$ deoxythymidine was added either directly to the cells, or under hypoxic culture conditions by plunging a spatula carrying appropriate quantity in dried form into the culture medium without opening the gassing vessel. To stop the incubations, medium was removed by aspiration and the cells were washed once with ice-cold phosphate buffered saline (PBS: $150 \mathrm{mM} \mathrm{NaCl} / \mathrm{P}_{\mathrm{i}} ; 10 \mathrm{mM} \mathrm{NaHPO}_{4}$, pH 7) and processed for analyses described below.

Analyses of the rate of incorporation of radioactive thymidine into $\mathbf{T 2 4}$ cells. For analyzing the incorporation of radioactive thymidine into hypoxic and normoxic T24 cells, the cells were prelabeled with $\left[{ }^{14} \mathrm{C}\right]$ Thd and grown for $44 \mathrm{~h}$. Subsequently, the experiment was started by medium renewal with fresh medium and the cultures were incubated for $5 \mathrm{~h}$ in hypoxic or normoxic incubation conditions. The cultures on $35 \mathrm{~mm}$ glass petri dishes were pulse-labeled for $15 \mathrm{~min}$ with $5.5 \mu \mathrm{Ci}^{3} \mathrm{H}$-thymidine and $2 \mu \mathrm{M}$ thymidine $\cdot \mathrm{mL}^{-1}$. The labeling was stopped by washing the cells with ice cold phosphate-buffered saline $\left(\mathrm{NaCl} / \mathrm{P}_{\mathrm{i}}: 150 \mathrm{mM} \mathrm{NaCl}\right.$, $10 \mathrm{mM} \mathrm{NaHPO}_{4}, \mathrm{pH}$ 7). The cells were lysed after trypsining for $5 \mathrm{~min}$ at $4^{\circ} \mathrm{C}$ and acid insoluble radioactivity was analyzed.

Alkaline sedimentation analyses of cellular DNA. For analyzing the length distribution of growing daughter strands of T24 DNA, the cultures were incubated hypoxically for $7 \mathrm{~h}$ or for hypoxically $7 \mathrm{~h}$ followed by $40 \mathrm{~min}$ reoxygenation conditions. The cultures on $35 \mathrm{~mm}$ glass petri dishes were pulse-labeled for $8 \mathrm{~min}$ with $7 \mu \mathrm{Ci}$ [methyl- ${ }^{3} \mathrm{H}$ ]deoxythymidine $\cdot \mathrm{mL}^{-1}$. Labeling was stopped by washing the cells with ice cold phosphate-buffered saline $\left(\mathrm{NaCl} / \mathrm{P}_{\mathrm{i}}: 150 \mathrm{mM}\right.$ $\mathrm{NaCl}, 10 \mathrm{mM} \mathrm{NaHPO}_{4}, \mathrm{pH}$ 7). The cells were trypsinized for $5 \mathrm{~min}$ at $4^{\circ} \mathrm{C}$ and layered onto the top of $10-30 \%$ alkaline sucrose gradients (Probst and Gekeler, 1980). After denaturation of the DNA for $6 \mathrm{~h}$, centrifugation was performed at 20,000 r.p.m., $23^{\circ} \mathrm{C}$ for $10 \mathrm{~h}$ in a Beckman SW28 rotor. $1.2 \mathrm{~mL}$ fractions were collected from the top of the gradient and processed to analyze acid insoluble radioactivity.

\section{Results}

Incorporation of radioactive thymidine into T24 cells. Fig. 1 shows the rate of incorporation of radioactive thymidine into T24 cells under hypoxic and normoxic incubation conditions. The ${ }^{3} \mathrm{H} /{ }^{14} \mathrm{C}$-ratio is relatively low in hypoxically incubated cells. This low rate clearly indicates no replicative activity in T2 4 cells. The ${ }^{3} \mathrm{H} /{ }^{14} \mathrm{C}$-ratio is increased almost 4 times by the treatment with PD184352 under hypoxia. This result clearly shows that PD184352 induces the incorporation of radioactive thymidine into T24 cells under hypoxic incubation condition. This induction of incorporation rate by PD184352 is completely

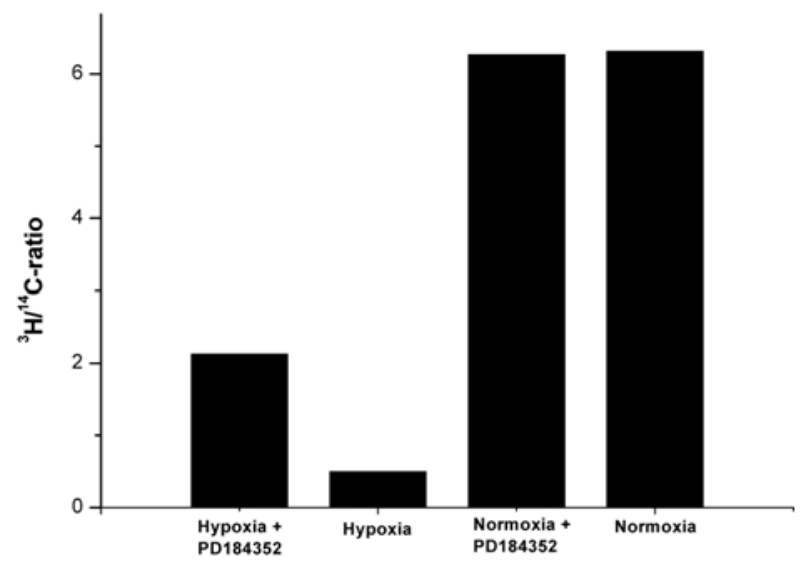

Fig. 1. Analyses of the rate of incorporation of radioactive thymidine into hypoxic and normoxic T24 cells. The cells were prelabeled with $\left[{ }^{14} \mathrm{C}\right]$ Thd and grown for $44 \mathrm{~h}$. Subsequently medium was renewed, PD184352 $(10 \mu \mathrm{M})$ was added, incubated hypoxically for $5 \mathrm{~h}$ and normoxically for $5 \mathrm{~h}$.

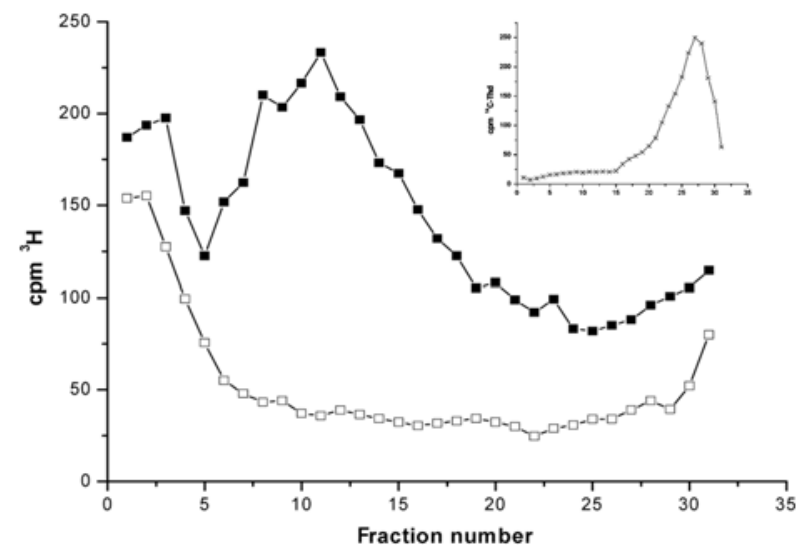

Fig. 2. Alkaline sedimentation analyses of growing daughter strands of hypoxic T24 cells. T24 cells were prelabelled with $\left[{ }^{14} \mathrm{C}\right]$ Thd and grown for $44 \mathrm{~h}$. Subsequently medium was renewed and incubated hypoxically for $7 \mathrm{~h}$. Nascent daughter strand DNA chains were pulse labelled with $7 \mu \mathrm{Ci}\left[\right.$ methyl $\left.{ }^{3} \mathrm{H}\right]$ deoxythymidine . $\mathrm{mL}^{-1}$. Inset, $\mathrm{x},{ }^{14} \mathrm{C}$-labelled matured bulk DNA. Main figure, $\square, 7 \mathrm{~h}$ Hypoxic incubation, $\boldsymbol{\square}, 7 \mathrm{~h}$ Hypoxic incubation and PD184352 $(10 \mu \mathrm{M})$ was added directly after medium renewal.

absent in normoxically incubated cells. The ratio of ${ }^{3} \mathrm{H} /{ }^{14} \mathrm{C}$ in PD184352 treated and untreated normoxic T24 cells are identical. These results clearly suggest that PD184352 induces the incorporation of radioactive thymidine into cells under hypoxic incubation condition and thereby PD184352 has no effect under normoxic incubation condition.

Alkaline sedimentation analyses of growing daughter strands. On the basis of numerous prior studies (Probst and Gekeler, 1980; Gekeler et al., 1986; Gekeler and Probst, 1988; Probst et al., 1988; Gekeler et al., 1993; Probst et al., 1999), $8 \mathrm{~min}{ }^{3} \mathrm{H}$-dThd pulses applied $7 \mathrm{~h}$ hypoxia and $40 \mathrm{~min}$ after 


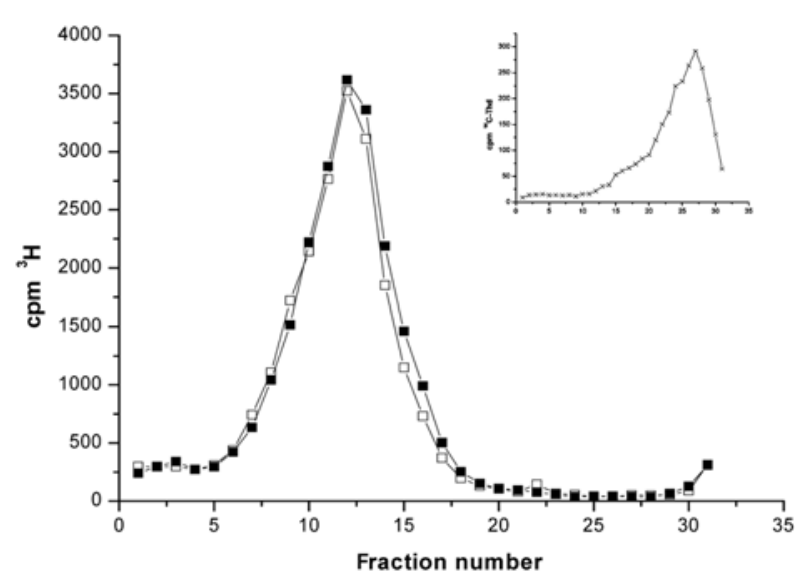

Fig. 3. Alkaline sedimentation analyses of growing daughter strands of reoxygenated T24 cells. T24 cells were prelabeled with $\left[{ }^{14} \mathrm{C}\right]$ Thd and grown for $44 \mathrm{~h}$. Subsequently medium was renewed and incubated hypoxically for $7 \mathrm{~h}$ and then reoxygenated for $40 \mathrm{~min}$. Nascent daughter strand DNA chains were pulse labelled with $7 \mu \mathrm{Ci}\left[\right.$ methyl- $\left.{ }^{3} \mathrm{H}\right]$ deoxythymidine $\cdot \mathrm{mL}^{-1}$. Inset, $\mathrm{x},{ }^{14} \mathrm{C}$-labelled matured bulk DNA. Main figure, $\square, 40 \mathrm{~min}$ reoxygenated after $7 \mathrm{~h}$ hypoxic incubation, $\mathbf{\square}, 40 \mathrm{~min}$ reoxygenated after $7 \mathrm{~h}$ hypoxic incubation and PD184352 $(10 \mu \mathrm{M})$ was added directly after medium renewal.

reoxygenation are turned out to be most convenient for demonstrating hypoxic replication arrest and initiation respectively. The cells were prelabeled with $\left[{ }^{14} \mathrm{C}\right]$ Thd when seeded, $44 \mathrm{~h}$ before the start of the experiment. The mature DNA of these cells contained a prelabel resulting from $\left[{ }^{14} \mathrm{C}\right]$ Thd added $44 \mathrm{~h}$ before. In Fig. 2 , the ${ }^{14} \mathrm{C}$ profile obtained typically exhibits a peak in the last third of the gradient. The gradient of hypoxic T24 cells contains almost no [ $\left.{ }^{3} \mathrm{H}\right] \mathrm{Thd}$, as expected according to the incorporation curve. Interestingly, a strong incorporation of $\left[{ }^{3} \mathrm{H}\right]$ Thd into growing daughter strands occurs in PD184352 treated hypoxic cell culture. Almost more than 4 times replication is reported in PD184352 treated hypoxic cell culture. This result suggests that PD184352 releases regular hypoxic replicon arrest and replicon is initiated under hypoxic incubation conditions. On the other hand, almost coincident prominent radioactivity peaks are reported in both PD184352 treated and untreated $40 \mathrm{~min}$ after reoxygenated cultures (Fig. 3). The prominent radioactive peaks represent the replicon initiation in course of reoxygenation. All the 2 profiles from reoxygenation and reoxygenation with PD184352 treated are identical. This result suggests that PD184352 shows no effect on replication initiation triggered by reoxygenation of hypoxic T24 cells. All the experiments were performed several times and the results were reproducible.

\section{Discussion}

In eukaryotes, the several hours of hypoxia arrests DNA replication reversibly and following reoxygenation induces a burst of replication initiation (Probst and Gekeler, 1980; Probst et al., 1988; Riedinger et al., 1992; Probst et al., 1999; Riedinger et al., 1999; Riedinger et al., 2002; van BetteraeyNikoleit et al., 2003). This $\mathrm{O}_{2}$-dependent regulation of DNA replication is an essential property of proliferating mammalian cells, serving basal function, such as protection against metabolic catastrophes during embryonic development or wound healing and in tumour growth (Probst et al., 1999). In T24 cells, several hours hypoxia arrests DNA replication reversibly, which is initiated in response to reoxygenation (van Betteraey-Nikoleit et al., 2003; Stabenow et al., 2005). So far, the mechanism involved is largely unknown. On the other hand, the cell cycle kinases are essential for replication and succeeding cell cycle. The suspicion was that hypoxia might have arrested the replicon initiation through cell cycle kinases. To determine this possibility, an inhibitor screening was carried out with different cell cycle kinase inhibitors (data not shown). Interestingly, PD184352 provides a new approach in oxygen dependent regulation of mammalian DNA replication. The analyses of incorporation of radioactive thymidine into hypoxic and normoxic T24 cells suggest that PD184352 induces the incorporation rate by almost 4 times more than control hypoxia. This increase in thymidine incorporation indicates the replicative activity in living hypoxic cells. PD184325-induced replicative activity is completely absent in normoxic incubated cells. This criteria is confirmed by alkaline sedimentation analyses of cellular DNA. Alkaline sedimentation analyses of the length distribution of pulse labeled daughter strand DNA indicates almost no replication under hypoxia (van Betteraey-Nikoleit et al., 2003; Stabenow et al., 2005). Interestingly, PD184352 releases the regular hypoxic replicon arrest without elevating the oxygen level. PD184352 induces replicon initiation in living hypoxic T24 cells, however, at a low intensity compared to the effect of reoxygenation. On the other hand, the sedimentation profiles of reoxygenated cells clearly represent the replicon initiation triggered by reoxygenation (van Betteraey-Nikoleit et al., 2003). The very similar profiles of reoxygenated and PD184352 treated reoxygenated cells suggest that PD184352 has no effect on replicon initiation triggered by reoxygenation. PD184352 is a well known inhibitor for ERK MAPK pathway (Dai et al., 2001; Milella et al., 2001; Squires et al., 2002). The treatment of PD184352 and thereby release of hypoxic replication arrest provides evidence for involvement of ERK MAPK pathway in oxygen dependent regulation of DNA replication. Moreover, this short communication provides a hint to initiate the hypoxically arrested DNA replication without elevating the oxygen level. However, the releasing mechanism of regular hypoxic replication arrest by PD184352 is largely unknown and to be determined.

Acknowledgments I wish to thank Prof. Hans Probst for encouragement, generous help and valuable discussion. 


\section{References}

Dai, Y., Yu, C., Singh, V., Tang, L., Wang, Z., McInistry, R., Dent, P. and Grant, S. (2001) Pharmacological inhibitors of the mitogenactivated protein kinase (MAPK) kinase/MAPK cascade interact synergistically with UCN-01 to induce mitochondrial dysfunction and apoptosis in human leukemia cells. Cancer Res. 61, 51065115.

Dreier, T., Scheidtmann, K. H. and Probst. H. (1993) Synchronous replication of SV 40 DNA in virus infected TC 7 cells induced by transient hypoxia. FEBS Lett. 336, 445-451.

Gekeler, V., Epple, J., Kleymann, G. and Probst. H. (1993) Selective and synchronous activation of early-S-phase replicons of Ehrlich ascites cells. Mol. Cell. Biol. 13, 5020-5033.

Gekeler, V. and Probst, H. (1988) Synchronization of replicons in Ehrlich ascites cells. Exp. Cell Res. 175, 97-108.

Gekeler, V., Stropp, U. and Probst, H. (1986) Application of hypoxiainduced shut down of replicon initiation to the analysis of replication intermediates in Ehrlich ascites cells. Biol. Chem. Hoppe-Seyler 367, 1209-1217.

Milella, M., Kornblau, S. M., Estrov, Z., Carter, B. Z., Lapillonne, H., Harris, D., Konopleva, M., Zhao, S., Estey, E. and Andreeff, M. (2001) Therapeutic targeting of the MEK/MAPK signal transduction module in acute myeloid leukemia. J. Clin. Invest. 108, 851-859.

Probst, G., Riedinger, H. J., Martin, P., Engelcke, M. and Probst, H. (1999) Fast control of DNA replication in response to hypoxia and to inhibited protein synthesis in CCRF-CEM and HeLa cells. Biol. Chem. 380, 1371-1382.

Probst, H. and Gekeler, V. (1980) Reversible inhibition of replicon initiation in Ehrlich ascites cells by anaerobiosis. Biochem. Biophys. Res. Commun. 94, 55-60.

Probst, H., Schiffer, H., Gekeler, V., Kienzle-Pfeilsticker, H., Stropp,
U., Stotzer, K. E. and Frenzel-Stotzer, I. (1988) Oxygen dependent regulation of DNA synthesis and growth of Ehrlich ascites tumor cells in vitro and in vivo. Cancer Res. 48, 20532060.

Riedinger, H. J., van Betteraey-Nikoleit, M. and Probst, H. (2002) Re-oxygenation of hypoxic simian virus 40 (SV40)-infected CV1 cells causes distinct changes of SV40 minichromosomeassociated replication proteins. Eur. J. Biochem. 269, 2383-2393.

Riedinger, H. J., van Betteraey, M. and Probst. H. (1999) Hypoxia Blocks In Vivo Initiation of Simian Virus 40 Replication at a Stage Preceding Origin Unwinding. J. Virol. 73, 2243-2252.

Riedinger, H. J., Gekeler, V. and Probst. H. (1992) Reversible shutdown of replicon initiation by transient hypoxia in Ehrlich ascites cells. Dependence of initiation on short-lived protein. Eur. J. Biochem. 210, 389-398.

Sebolt-Leopold, J. S., Dudley, D. T., Herrera, R., Van Becelaere, K., Wiland, A., Gowan, R. C., Tecle, H., Barrett, S. D., Bridges, A., Przybranowski, S., Leopold, W. R. and Saltiel, A. R. (1999) Blockade of the MAP kinase pathway suppresses growth of colon tumors in vivo. Nat. Med. 5, 810-816.

Squires, M. S., Nixon, P. M. and Cook, S. J. (2002) Cell-cycle arrest by PD184352 requires inhibition of extracellular signal-regulated kinases (ERK) 1/2 but not ERK5/BMK1. Biochem. J. 366, 673680.

Stabenow, D., Probst, H. and Betteraey-Nikoleit, M. (2005) Cdk2 activity is dispensable for triggering replicon initiation after transient hypoxia in T24 cells. FEBS J. 272, 5623-5634.

van Betteraey-Nikoleit, M., Eisele, K. H., Stabenow, D. and Probst, H. (2003) Analyzing changes of chromatin-bound replication proteins occurring in response to and after release from a hypoxic block of replicon initiation in T24 cells. Eur. J. Biochem. 270, 3880-3890. 